\title{
National business regulations and city entrepreneurship in Europe: a multilevel nested analysis
}

Article

Accepted Version

Audretsch, D. B., Belitski, M. and Desai, S. (2018) National business regulations and city entrepreneurship in Europe: a multilevel nested analysis. Entrepreneurship Theory and Practice. ISSN 1540-6520 doi:

https://doi.org/10.1177/1042258718774916 Available at https://centaur.reading.ac.uk/77784/

It is advisable to refer to the publisher's version if you intend to cite from the work. See Guidance on citing.

To link to this article DOI: http://dx.doi.org/10.1177/1042258718774916

Publisher: SAGE Publications

All outputs in CentAUR are protected by Intellectual Property Rights law, including copyright law. Copyright and IPR is retained by the creators or other copyright holders. Terms and conditions for use of this material are defined in the End User Agreement.

www.reading.ac.uk/centaur 
Central Archive at the University of Reading

Reading's research outputs online 


\title{
National Business Regulations and City Entrepreneurship in Europe: A Multi-level Nested Analysis
}

\author{
David B. Audretsch \\ School of Public and Environmental Affairs, Indiana University Bloomington \\ 1315 E. 10th Avenue SPEA Bloomington, IN 47405, USA \\ Email: daudrets@indiana.edu \\ Maksim Belitski \\ Henley Business School, University of Reading \\ Whiteknights campus, Reading, RG6 6UD, UK \\ Email: m.belitski@reading.ac.uk \\ Sameeksha Desai ${ }^{1}$ \\ School of Public and Environmental Affairs, Indiana University Bloomington \\ 1315 E. 10th Avenue SPEA Bloomington, IN 47405, USA \\ Email: desai@indiana.edu
}

\begin{abstract}
This paper provides and tests a theoretical framework with a multilevel (country-city) nested model to analyze the relationship between national business regulations and city level entrepreneurship. While public interest theory predicts a positive relationship between national business regulation and city level entrepreneurship, public choice theory predicts the opposite, a negative relationship. Based on multilevel analysis for a matched country-city panel of 228 cities across 20 European countries for the years 2004-2009, the empirical evidence from panel data estimation explains how changes in national business regulations influence changes in city level entrepreneurial activity over time.
\end{abstract}

Keywords: Entrepreneurship, City, Government Policy, Regulation, Europe, Multi-level

JEL: L26 M13 R10 O17

Acknowledgements: The authors thank Zoltan Acs, Johan Eklund, Sergio Fernandez, Leora Klapper, Ashlyn Nelson, Bob Rijkers, and participants at the World Bank's 2014 Doing Business conference. Sean Webeck provided valuable research assistance.

\footnotetext{
${ }^{1}$ Corresponding author
} 


\section{INTRODUCTION}

Research on the drivers of systematic variations in entrepreneurship can be grouped into two streams. The first is entrepreneurship and regional economic development (Audretsch et al., 2015; Bosma and Sternberg, 2014; Boschma and Fritsch, 2009), and the second is cross-country research on institutions and entrepreneurship (Spigel, 2017; Autio et al. 2014; Stenholm et al., 2013; Ardagna and Lusardi, 2010; Bruton et al. 2010; Acs et al., 2008a; van Stel et al., 2007).

Despite theoretical underpinnings on the importance of institutions for entrepreneurship (Baumol, 1990; North, 1990), little theoretical work asks how country level institutions impact entrepreneurship in cites (Audretsch and Belitski, 2017; Hundt and Sternberg, 2016). This represents a knowledge gap on the impact of the country context on entrepreneurship in subnational units, such as cities (Charron et al., 2014). City level studies on entrepreneurship and economic development often ignore the country context in which cities are embedded (Spigel, 2016, 2017; Charron et al., 2014) while country level studies on regulations and entrepreneurship suffer from potential loss of nuance due to aggregation. Although the entrepreneur is embedded in the city context (Autio et al. 2014; Fritsch and Storey, 2014), he or she also operates in the country (Braunerhjelm et al., 2015; Autio et al., 2014; Whitley, 1999). Thus, country level conditions like regulations are not optional: entrepreneurs in all cities must comply.

To rectify this, we offer and test a theoretical framework with a multilevel (country-city) nested model linking national business regulations (NBR) and city level entrepreneurship. We argue that public interest theory implies a positive relationship between NBR and city level entrepreneurship, whereas public choice theory implies the opposite. Rooted in these theories, we hypothesize that the relationship between NBR and city level entrepreneurship is an inverted U-shape. We also argue that there is an optimum level of NBR for city entrepreneurship. 
For the purposes of our study, we include four types of NBR related to entry, property registration, taxes, and contract enforcement. For each, we use one measure for the procedures needed to meet regulatory requirements and one measure for the costs of meeting requirements. City level entrepreneurship reflects new ventures, between one and three years old, as a share of total businesses in a city. We test our inverted U-shape hypothesis using multilevel analysis on a matched country-city panel of 228 cities across 20 European countries, over the period 20042009. We find partial support for our hypothesis. We also find that country level characteristics explain more of the systematic variation in city level entrepreneurship than city characteristics.

We use panel data techniques, which enable us to infer causality on how changes in NBR affect changes in city entrepreneurship over time. We advance cross-sectional research on regulation and entrepreneurship (Stenholm et al., 2013; Adargna and Lusardi, 2009, 2010), and we extend past research which usually assumes a linear negative impact of regulation on entrepreneurship (Braunerhjelm et al., 2015). Our study answers calls for multilevel research (Ding et al., 2015; Westlund et al., 2014; Hundt and Sternberg, 2016), insight on crossnational institutional variation (Welter, 2011), dynamics of entrepreneurs in broader context (Autio et al., 2014), and drivers of urban entrepreneurship (Glaeser et al., 2010b). Our results can inform location choices of entrepreneurs considering city or country factors, and can help policy optimize the impact of NBR on entrepreneurship in cities.

\section{THEORETICAL FRAMEWORK}

\section{Entrepreneurship in cities}

Research on entrepreneurship in cities has benefited from insights from several fields, including regional economics and economic geography (Jacobs, 1970; Marshall, 1890), and has 
been tested in city level empirical studies. While studies have analyzed why entrepreneurial activity varies across cities (Spigel, 2016; Belitski and Desai, 2015; Armington and Acs, 2002; Reynolds et al., 1994), they have not considered the particular country context and country specific characteristics. These are rooted in agglomeration economies, which present opportunities for entrepreneurs, tied to factors like clustering, financial services depth, and human capital (Armington and Acs, 2002).

Past research has found that local demand, market size (Boschma and Fritsch, 2009) and regional purchasing power (Reynolds et al., 1994; Bergmann and Sternberg, 2007) can attract entrepreneurs. It is reasonable to expect this differs across cities located within a country. Bigger cities offer large market opportunities despite possibly burdensome national regulations (i.e. profits larger than regulatory costs). Larger agglomeration economies offer spatial concentrations of human capital (Audretsch et al., 2015), which is conducive to potential entrepreneurs and new firms seeking employees (Boschma and Fritsch, 2009). Industry mix in a city matters (Marshall, 1980; Jacobs, 1970; Belitski and Desai, 2015) because some industries are more salient for entrepreneurs (see Davidsson et al., 1994). For example, higher concentration of financial, professional and business industries can boost entrepreneurship (Keebler and Walker, 1994).

\section{Country level regulation and city level entrepreneurship}

Research on regulation and entrepreneurship at the country level suggests that a functional regulatory environment incentivizes entrepreneurs (Estrin et al., 2013; Stenholm et al., 2013; Ardagna and Lusardi, 2010; Acs et al., 2008a; Klapper et al., 2006). The nuances of the regulatory environment, however, are not well understood, such as which particular regulations matter for specific entrepreneurship outcomes (Audretsch et al., 2015). 
The concept of a national business system (Whitley, 1999) contends that firms do not exist in a vacuum. Rather, they are economic units affected by the business environment. This is intuitive: entrepreneurs operate in markets which are governed by laws and regulations. These are closely tied to local context, including institutional and geographic constraints. Whitley (1999) argues that some influences are geographically restricted to the home region of the firm, while another set of influences is linked to broader institutions. The national business systems concept (Whitley 1999) highlights the need to consider links between the country and city levels. Consistent regulatory design governing all entities within a country reflects the national business system, which shapes entrepreneurship (see Whitley, 1999). At the same time, entrepreneurship occurs within a local context, with constraints like availability of workers and infrastructure. In this way, entrepreneurship is also an urban event (Bosma and Sternberg, 2014).

We therefore ask: how do NBR influence city level entrepreneurship? Our nested multilevel model is in Appendix (Figure 1). Entrepreneurship occurs in a city (Feldman, 2001), embedded inside a country, and thus subject to NBR (Whitley, 1999). Our goal is to identify the size and direction of the relationship between heterogeneous NBR and city level entrepreneurship, rather than analyze differences in national and city level entrepreneurship. We point out that country level studies capture net effects, but city level entrepreneurship needs deeper study of trends within and between countries, which can vary greatly (Charron et al., 2014). Prior comparative research on entrepreneurship in cities suffers from a key limitation: it has been largely done within, not between, countries. Most studies have been conducted within one region or country, e.g. Germany (Fritsch and Mueller, 2007), United States (Armington and Acs, 2002), Scotland (Spigel, 2016). Few studies examine cities in several countries, despite the need for contextual insight (Belitski and Desai, 2015; Hundt and Sternberg, 2016). We rectify 
this by injecting the country level into the question of variations in city level entrepreneurship. We focus on NBR, which is consistent for all cities in a country.

National institutions can set rewards and expected payoffs for entrepreneurship (Baumol, 1990), and NBR represents a subset of formal institutions which are explicit, codified, and govern businesses (Williamson, 2000). Entrepreneurs adapt to their institutional context (van Stel et al., 2007) by responding to institutions governing the entry and early life of a firm (Acs et al., 2008a). Transactional trust (Fogel et al., 2006) reflects the extent to which entrepreneurs trust regulations which affect firm transactions, such as how they raise capital, enter new markets, enforce contracts, pay taxes and so on (Djankov et al., 2002). Regulation is heterogeneous (Braunerjhelm et al., 2015; Estrin et al., 2013; Williamson, 2000) and can vary by type (e.g. entry regulation, property registration regulations), highlighting the need to consider that the relationship between regulations and entrepreneurship could manifest in different ways.

Two contrasting economic theories of regulation explain why we can expect a complex non-linear relationship between NBR and entrepreneurship. Public interest theory (Pigou, 1938) posits that regulation is generally devised to protect the public at large (Hantke-Domas, 2003). Regulation is enacted by benevolent politicians in order to correct market failures, ensure the quality of products and improve public welfare (Pigou, 1938). In this view, regulation helps the public by weeding out "bad" entrepreneurs who would have wasted precious resources and failed or taken advantage of consumers, from "good" entrepreneurs who create welfare gains. Regulations also protect entrepreneurs by ensuring things like access to working courts, clear knowledge about tax policies, and equitable access to rules and information. A public interest perspective suggests we should expect a positive relationship between NBR and city level entrepreneurship. 
In contrast, public choice theory argues that regulation is used by powerful agents to improve their own economic gains (see Djankov et al., 2002; Peltzman, 1976; Tullock, 1967). Agents can be incumbent firms that pursue regulation to protect profits, and engage in lobbying and regulatory capture to raise entry barriers and limit competition. Agents can also be politicians who enact regulation to create rents and govern the process of collecting them. More complex regulations can benefit rent-seeking politicians (De Soto, 1989) if they yield direct revenues and offer more opportunities to extract bribes (Belitski et al., 2016). This "politics without romance" view reflects a realistic picture of regulation (Eskridge, 1988: 276, quoting Buchanan), especially in some developing countries (Chowdhury et al., 2015). Access to political and judicial power can influence decisions; public officials with this power can design and enforce rules with discretion. This is similar to a private toll road (see Djankov et al., 2002) which all entrepreneurs must use, but where officials are toll collectors and enforcers. For example, if an entrepreneur must file six forms to pay taxes, this offers six opportunities for a government agent to extract payment. A public choice perspective suggests that we should expect a negative relationship between NBR and city level entrepreneurship.

Both theories offer insight into the origins of NBR, suggesting two dynamics: effective, conducive NBR encourages entrepreneurship (public interest) but excessive, cumbersome NBR discourages entrepreneurship (public choice). These opposing effects could occur across different types of NBR. For example, a public-serving regulator in a country's land registration agency could enact conducive regulations, whereas a self-serving regulator in the same country's national tax authority could enact cumbersome regulations. Also, job change and staffing replacements, such as during changes in government administration or even the natural career trajectories of individual regulators, can bring a significantly different approach and style of 
regulating within the same agency at different times. We expect the relationship between NBR and city level entrepreneurship is likely to take the form of an inverted U-shape. We thus hypothesize that:

Hypothesis: The relationship between national business regulations (NBR) and city level entrepreneurship is an inverted $U$-shape.

\section{DATA AND VARIABLES}

Our matched sample is built from Eurostat's European Urban Audit, the World Bank Doing Business database, and Transparency International's Corruption Perceptions Index. The Urban Audit is a standardized database of European cities which covers the period 1994-2009. It offers a rich range of economic, political, social and cultural indicators for European cities, with a core city defined to contain at least 50,000 residents. All European capitals and major regional cities are included, so it is appropriate to study trends in cities over time and space. The Urban Audit is the source for our dependent variable and for many of our control variables.

The Doing Business database measures a wide range of national business regulations beginning in 2003, and is standardized to be comparable across countries. Given that the Urban Audit is collected every three years (2000-2004, 2004-2006, 2007-2009; reporting years 2005, 2007, 2010), we take the equivalent years of Doing Business data for our explanatory variables capturing NBR $(2004,2006,2008)$. This links entrepreneurship data from the Urban Audit with regulatory data from Doing Business for the appropriate periods. Our final sample is longitudinal data comprising 228 cities in 20 European countries and 496 observations, over the years 20042009. Table 1 contains correlations and descriptive statistics for our variables.

-INSERT TABLE 1 ABOUT HERE- 


\section{Dependent variable}

City level entrepreneurship is our dependent variable, measured as new firm formation in a city, and calculated using the ratio of new business ventures between one and three years old to the total number of existing businesses. The data come from the Urban Audit and includes all periods in our study. A graphical depiction of our dependent variable can be found in the Appendix (Figure 2).

\section{Explanatory variables}

Our explanatory variables capture NBR and are all taken from the Doing Business data. Specifically, we focus on four aspects of NBR, related to entry, property registration, taxes, and contract enforcement. We use two dimensions of each regulation: procedures, measured as the number of procedures needed to complete the regulatory requirements, and cost, measured as the financial costs associated with completing the requirements. For each of the NBR variables, we also take their squared terms. We enter the variables into one model, and investigate them at the single variable level (not as an index). Although the four aspects of regulation do not cover all possible NBR that can influence individual entrepreneurial behavior (e.g. tariffs and non- tariff barriers, safety and environmental standards) (Ardgana and Lusardi, 2010), they include some of the most important regulatory constraints across countries.

Entry regulation reflects the entry burden for an entrepreneur to incorporate a business. It is measured using the number of procedures required to start a local limited liability company, and the cost of the process as percentage of income per capita. Prior research found that more entry regulation deters entrepreneurship (Ciccone and Papaioannou, 2007; Klapper et al., 2006; Djankov et al., 2002, 2009). Entry regulation imposes costs early on, often before cash flows, so 
entrepreneurs with strong prospects may be willing to take on the costs. For this reason, some entrepreneurs may be willing to accept higher entry regulation, while others may not.

Registering property matters because secure property rights can create channels for collateralization (see De Soto, 1989; Williamson, 2000), which could improve access to finance for entrepreneurs. This is measured using the number of procedures required to register property and as the cost of complying with the regulations as a percentage of the property value. Transparent and clear property rights could reduce risks to lenders or investors (Estrin et al., 2013), and security of property can raise confidence about investing in assets like buildings (Desai et al., 2014).

Tax regulation has been found to negatively affect entrepreneurship (Acs et al., 2008b). Entrepreneurs may see paying taxes as cutting into business resources (Baliamoune-Lutz and Garello, 2014). Procedures to pay taxes is measured as the number of required tax payments, and costs reflects the total tax rate as a percentage of profits. In a study of corporate income taxes in 85 countries, Djankov et al. (2009) found a negative impact on new business. However, it is also possible that "a benevolent social planner who wants to spend significant resources on screening new entrants may choose to finance such activity with broad taxes rather than with the direct fees" (Djankov et al., 2002: 8). Taxes provide public revenues to finance resources that can help entrepreneurs, like schools and infrastructure. Tax morale and willingness of entrepreneurs to comply with regulations could be shaped by what they "get back" (Belitski et al., 2016).

Contract enforcement regulation can shape confidence about forming relationships (e.g. with suppliers) and the security of claims to receive returns (Johnson et al., 1999). It is measured as the number of procedures needed to enforce contracts, and as the costs of enforcement as a percentage of the claim value. New firms and incumbents face the same costs to enforce 
contracts, but incumbents can exploit information asymmetries due to longer standing in the market and more opportunities to cheat (Estrin et al., 2013). If enforcement costs are low, entrepreneurs may conclude they will be able to enforce contracts. However, if costs are too low or it is too easy to go to court, entrepreneurs may fear vulnerability to arbitrary claims.

\section{Control variables}

We use several city level controls from the Urban Audit Project to reflect local conditions related to industry structure, agglomeration economies, workforce and corruption (Bosma and Sternberg, 2014; Glaeser et al., 2010a; Fritsch and Mueller, 2007). Population at work (16-65 years old), taken in logarithm, is used to capture the level of employment (Estrin et al., 2013). We use population density in logarithm, to account for market size (Boschma and Fritsch, 2009) because regional purchasing power (Bergmann and Sternberg, 2007) can attract entrepreneurs. Higher population density could mean more market opportunities and access to higher concentration of skilled people (Audretsch et al., 2015; Reynolds et al., 1994).

Employment structure across city industry is measured using the European standard industry classification (NACE) to control for human capital returns to entrepreneurship across different industries (Belitski and Desai, 2015). We select six aggregated sectors, measured by proportion of employment per sector, including: agriculture; manufacturing; retail; finance; public (administration, healthcare, education); and information-communication technologies (ICT). The six sectors are compared against a combined reference category (construction, creative industry, transport, other services). Grouping of the reference category is due to small shares of each sector in total employment, and is done to avoid perfect multicollinearity.

Economic development, measured as GDP per capita in purchasing power parity (PPP) (NUTS3 level), is as an economic performance indicator for cities (Ardagna and Lusardi, 2010). 
Since economic performance proxies can have a nonlinear relationship with entrepreneurship (Estrin and Mickiewicz, 2012), we also include the squared term for economic development. To account for the possibility that corruption raises costs and delays entry (Estrin et al. 2013;

Klapper et al., 2006), we use Transparency International's Corruption Perceptions Index (CPI). This is measured at the country level with a minimum value of zero and maximum of ten. CPI is highly correlated with EU integration and Eurozone status, so we omit these indicators.

To address potential omitted variable bias related to unobserved city-characteristics, we use city-type fixed effects, proxied using 13 city typology dummies identified by the European Commission (2007). Three typologies represent international hubs with pan-European or global influence: knowledge hubs, established capitals and re-invented capitals (e.g. Milan, Stockholm). Another six typologies represent cities serving as specialized poles which can play an important role in at least some aspect of the urban economy: national service hubs, transformation poles, gateways, modern industrial centers, research centers, visitor centers (e.g. Marseille, Seville). The remaining four typologies represent regional poles: de-industrialized cities, regional market centers, regional public service centers, satellite towns (e.g. Poznan, Dresden, Manchester). The gateways typology serves as reference category. The city typologies have low correlations with the other variables $(<0.25)$, except for knowledge hubs with economic development $(0.66)$ and established capitals with population density $(0.55)$. We also used time fixed effects to control for factors which vary within a city over time and can be applied to all cities (Certo et al., 2016).

\section{DATA ANALYSIS}

We apply a nested multilevel model where cities are located (clustered) in countries. Our dependent variable is at the city level, and not nested within a city. The multilevel regression 
contains fixed and random effects. Fixed effects are directly estimated, in addition to indirectly estimated by covariances of random intercepts and slopes (see McCulloch et al., 2008; RabeHesketh and Skrondal, 2012).

The panel data include information on within-city and between-city variance. This lets us consider whether conditions across cities (between-city) and changes in conditions within cities (within-city) affect city entrepreneurship (see Certo et al., 2016). Multilevel regression yields a mixed model where we estimate variation within and between cities. This model specification has its origin in Papke and Wooldridge (2008). Formally, a two-level model was estimated with the dependent variable $y_{i j t}$ and the independent variable $x_{i j t}$ such that:

$$
y_{i j t}=\beta_{0}+\beta_{1} x_{i j t}+\varepsilon_{i j t}
$$

where $\mathrm{i}$ is the city level- $1, \mathrm{j}$ is the country level-2, and $\mathrm{t}$ serves to index the wave survey. Dependent variable $y_{i j t}$ is city level new business formation. Explanatory variables, described earlier, are presented by $x_{i j t}$. Finally, $\varepsilon_{i j k}$ is an error term that, in the hierarchical model, consists of three components:

$$
\varepsilon_{i j t}=\gamma_{i \cdot .}+\mu_{i j .}+v_{i j t}
$$

where $\gamma_{i .}$. represents the omitted variables that vary across cities but not over countries and time, $\mu_{i j}$. denotes the omitted variables that vary over countries but are constant across cities and overtime, and $v_{i j k}$ is the error term.

Our two-level model includes 228 cities over 2004-2009. The random intercept captures unobserved heterogeneity at the country level, and is assumed to be independent and normally distributed with zero mean and constant variance. The error terms are assumed to be independent and can therefore be directly estimated (Goldstein, 2005). There is no statistical justification for 
imposing a particular covariance structure between random effects at the start, so we estimate a model with unstructured random-effects covariance matrix (Rabe-Hesketh and Skrondal, 2012).

Post-estimated predictive margins were calculated from predictions of a previously fit model at fixed values of some covariates, and averaging or otherwise integrating over the remaining covariates. We do this for the four aspects of NBR, using both the procedures and costs measures. Post-estimated predictive margins are a tool to explain a relationship when the sign changes. They estimate the margins of responses for specified values of covariates using $95 \%$ confidence intervals, to measure boundaries of the effect of NBR on city level entrepreneurship.

We point out that Lind and Mehlum (2010) argued that conventional means for testing nonlinearities are inadequate, and proposed additional testing beyond significance and signs of coefficients. In line with their approach, after calculating predictive margins, we also test for inverted U-shape relationships and inflection points.

\section{RESULTS}

\section{Hypothesis testing}

Table 2 contains results from the mixed-effects estimation testing the hypothesized inverted U-shape relationship between NBR and city level entrepreneurship. The baseline model (Specification 1, Table 2) has a statistically significant random intercept, which indicates multilevel modeling is most appropriate for our purposes (McCulloch et al., 2008). Also, the LR test comparing the model with one level ordinary linear regression is significant, advocating multilevel modelling. Interclass correlation coefficients (ICC) demonstrate that a large part of the variance in city level entrepreneurship is due to between country differences. ICC is between 89 
percent for procedures related to NBR (Specification 2) and 78 percent for costs of NBR (Specification 3). We also perform poolability test of regression coefficients, checking that 228 cities can be pooled together. F-statistic varies from 12.36 to 21.32 (fixed effects), implying rejection of the null hypothesis of constant effects, justifying the panel data approach (Wooldridge, 2002).

---INSERT TABLE 2 ABOUT HERE---

We found that urban industry mix, employment in services, transport, financial intermediation and creative sectors encourage city level entrepreneurship. Level of economic development has non-linear association with city level entrepreneurship (Thurik et al. 2008). Finally, the employed population positively affects city level entrepreneurship.

The results in Table 2 partially support an inverted U-shape relationship between four NBR and city level entrepreneurship. Our results for NBR related to entry provide partial support for our hypothesis and identify a nonlinear influence of NBR related to entry on city level entrepreneurship, with contrasting effects for entry procedures and entry costs. An increase in entry procedures has an inverse U-shape relationship with city level entrepreneurship ( $\beta=6.37$, $p<0.01 ; \beta=-0.48, p<0.01)$. Up to seven entry procedures encourages entrepreneurship, after which it falls, indicating that seven procedures is an optimal policy target. In contrast, we found a U-shape relationship between the cost of entry regulation and entrepreneurship $(\beta=-1.11, p<$ 0.01 and $\beta=0.02, p<0.01$ ). Entry costs deter entrepreneurship up to a threshold of 20 percent of income per capita.

Our results for NBR related to property registration do not support our hypothesis. We found a $\mathrm{U}$-shape influence for property registration procedures $(\beta=-21.43, p<0.01$ and $\beta=$ $1.57, p<0.01)$ and costs $(\beta=-4.53, p<0.01 ; \beta=0.28, p<0.01)$ on city level entrepreneurship, 
with the effect being weaker for costs. NBR related to property registration discourages city level entrepreneurship, which falls to zero at six procedures and at nine percent of costs, after which it grows with more procedures and higher costs. This is in line with Ardagna and Lusardi (2010), who found a varied effect of regulation on necessity and opportunity driven entrepreneurship in a country. For example, in countries that are more heavily regulated but also have lower economic development status, the threshold for regulation could be higher (see Thurik et al. 2008).

We do not find support for our hypothesis when it comes to NBR related to tax regulation. The relationship between tax payments and city level entrepreneurship is negative ( $\beta$ $=-0.17, p>0.10$ and $\beta=0.89, p>0.10$ ). This is consistent with some previous research (Acs et al., 2008b; Baliamoune-Lutz and Garello, 2014) that has found more tax payments reduces entrepreneurship. City level entrepreneurship is likely to be zero when the number of tax payments exceeds 35 . The cost of taxes has a $\mathrm{U}$-shape relationship $(\beta=-2.87, p<0.01 ; \beta=0.03$, $p<0.01$ ) with city level entrepreneurship: it falls when the tax rate reaches $35-40$ percent, and then it rebounds again. The result is driven by Eastern European cities with high entrepreneurship rates, but also low financial development and high taxes.

Our findings provide support for NBR related to enforcing contracts. Although beta coefficients in Table 2 are not statistically significant, predicted margins in Appendix (Figure 3) demonstrate an inverted U-shape relationship holds for a very specific interval. The inverted Ushape relationship for contract procedures and city level entrepreneurship was found at between 36 and 42 procedures, while the relationship between contract costs and city level entrepreneurship was found between 12 and 28 percent of the claim value. This is consistent with research on the need for a conducive level of costs to enforce contracts (Johnson et al., 1999) to protect entrepreneurs. Graphical representation of the results is illustrated in Figure 3. 


\section{Robustness Checks}

We conduct four types of robustness checks. High levels of entrepreneurship in German cities compared to other European cities (Figure 2), coupled with generally more complex NBR suggests an additional robustness check of our findings. We reduced our sample to 189 cities in 21 countries excluding German cities (Table 2, specifications 4 and 5). The country level gains explanatory power in explaining city entrepreneurship: we find an ICC of 92 percent for procedures and 76 percent for costs related to NBR. The reduced sample yields similar results for the direction and significance of explanatory variables, with different magnitudes and inflection points for inverted U-shape and U-shape relationships. Notably, the inflection point for entry procedures falls to four procedures when German cities are excluded (seven procedures in the full sample). The result for tax procedures is similar: 20 payments when German cities are excluded (30 payments in the full sample).

Results for predictive margins provide partial support for an inverted U-shape relationship in two types of NBR (related to entry, contracts) with city level entrepreneurship. In contrast, a U-shape relationship is found for cost of paying taxes and cost of property registration. This brief exercise without German cities suggests that future research consider the role of unique country context for entrepreneurship in Germany (Audretsch and Lehmann, 2016).

Beyond the analyses shown in Table 2 and Figure 3, we statistically verify the inverted U-shape relationships (Lind and Mehlum, 2010). We did this for eight potential relationships related to our main hypothesis. We corroborate the findings in Figure 3. The size of the effect of the U-shape relationship remains consistent across all NBR related to entry, property registration, and contract enforcement. Beta-coefficients and U-test jointly show that across NBR related to entry cost and contract enforcement, the size of the inverted U-shape relationship remains stable. 
For NBR related to entry procedures and property rights, a U-shape relationship was found.

More specifically, the test calculates an optimum point (number of procedures or cost) where the NBR contributes most to city level entrepreneurship.

In addition, we explore whether four types of NBR have a nonlinear association with city level entrepreneurship. We started by estimating each NBR measure in levels, then using squared terms. This allowed us to identify nonlinearities and establish a form of relationship. We also calculate plotted predicted margins for procedures and costs of each NBR, using Delta method. The F-test for nonlinearities, plotted predictive margins of each regulation type locally weighted regressions also support results in Figure 3.

Finally, we standardize all country level variables. We created standardized values and specified the desired mean of zero and standard deviation of one, producing a new variable with mean zero and standard deviation unity. We do this so NBR is comparable across countries and cities (Wooldridge, 2002). Confidence intervals and predictive margins built on standardized values of NBR procedures and costs all support the findings in Table 2 and Figure 3.

\section{DISCUSSION}

Our study highlights the importance of using multilevel modeling to understand the impact of NBR on city level entrepreneurship. The nested approach applied in our analysis provides clear insights on the multilevel embeddedness of entrepreneurship. Given that both city and country characteristics are important for city level entrepreneurship, we suggest that city policymakers can actively enhance or mitigate the influence of NBR for their own cities. We tested the hypothesis that NBR has an inverted U-shape relationship with city level entrepreneurship. We found partial support for entry regulation and weak support for contract 
regulation (where the hypothesis is valid within a limited interval). In contrast, we found an Ushape relationship for paying taxes (cost only), for property registration and entry cost. We suggest that heterogeneity in the effect of NBR on city level entrepreneurship is an important question for future research, and could be investigated with the lens of opportunity and necessity entrepreneurship in a city and country (Van Stel et al., 2007).

Although we find partial support for our hypothesis, we establish evidence that the relationship between NBR and city level entrepreneurship is non-linear and this varies across the type of NBR as well as the way it is undertaken (procedures or cost). Nonlinearities tell much of the story about the influence of NBR in city level entrepreneurship than the usually linear negative effect that emerges from the country level research (Stenholm et al., 2013; Estrin et al., 2013; Ardagna and Lusardi, 2010; Klapper et al., 2006). Deeper investigation of nonlinearities should be a priority for future research.

Our results show that NBR related to property registration and taxes are more consequential for city level entrepreneurship than NBR related to entry and contract enforcement. In other words, the marginal increase/decrease in city level entrepreneurship corresponding to one unit increase in regulation is larger for property registration and taxes than for entry and contract enforcement (see Figure 3). We also find that city level entrepreneurs are more sensitive to changes in procedures to comply with regulation than financial costs: a unit change in procedures related to entry and property registration have a higher marginal effect than a unit change in costs (Figure 3). This implies that policymakers seeking fast results could prioritize reforms in procedural or administrative requirements. Our results highlight the importance of considering not only the type of NBR (e.g. entry versus taxes) but also the way regulations are implemented (e.g. by making changes to procedures or financial costs). 
We contribute to entrepreneurship research in three ways. First, we use an institutional lens to link NBR and city level entrepreneurship (Djankov et al., 2009; Whitley, 1999; Baumol, 1990, North, 1990), advancing sparse research on country factors and subnational outcomes (Bosma and Sternberg, 2014). In doing so, we determine that key assumptions about size and role of regulation on entrepreneurship should be reconsidered (Spigel, 2017; Autio et al. 2014).

Second, we advance knowledge on institutions and entrepreneurship by delineating how public interest and public choice theories of regulation can explain the effect of NBR on city level entrepreneurship. We urge regulators, particularly in regions like Europe where moving between countries is easier, to reconsider the conventional "less is better" approach in favor of "smarter" regulation providing a favorable policy mix for entrepreneurship.

Third, we make a methodological contribution to entrepreneurship research by using a multilevel model comprising both country level and city level characteristics (Certo et al., 2016). Our findings demonstrate the value of exploiting multilevel analysis in entrepreneurship research (Ding et al., 2015; Westlund et al., 2014; Hundt and Sternberg, 2016).

Our work highlights the need for scholars to carry out a research agenda on within- and between- country effects of NBR and their relationship with subnational entrepreneurship outcomes. Some theoretical and methodological limitations of our study can be addressed in further research. First, our dependent variable does not capture if the motivation for entrepreneurship is opportunity or necessity driven, which could shift the threshold entry across various NBR (see Ardagna and Lusardi, 2010). The Urban Audit data do not allow us to measure the overall direct size of the effect in employment terms, since the data on new business formation does not include jobs. Future research could attempt to connect employment with new business formation, to assess how NBR influence specific types of city level entrepreneurs. 
A fruitful path for future research is to further unpack heterogeneity of NBR beyond the four types covered in our study. These could include, for example, NBR related to tariffs, exports, labor markets, finance, and bankruptcy. Related to this is the need to unpack other types crossnational institutional variation (see Welter, 2011), like corruption. This could be particularly interesting given the differences between cities in Germany and other countries.

Also, the sectoral distribution of entrepreneurial activity across cities is not available in our sample. Some cities attract entrepreneurs in some sectors, e.g. IT in Berlin, and some cities may be marked by entry in other sectors or by founders, e.g. immigrants (e.g., Birmingham, Paris, London, Marseille) $)^{2}$. NBR can have varied industrial and geographic effects on different types of entrepreneurs, which could vary based on where they tend to cluster. Future data efforts could enable fine-grained analysis of these questions.

The endogeneity of regulation may be a less relevant challenge for our study, but we are only able to consider our estimates with one period (three year) lagged explanatory and control variables. Our results are robust but the significance of coefficients drops and the size of the confidence intervals increases once we apply lagged values. Future research should attempt more frequent data collection to lengthen the time period to address potential endogeneity issues.

\section{References}

Acs, Z., Desai, S., \& Klapper L., (2008a). What does entrepreneurship data really show? Small Business Economics 31(3), 265-281.

Acs, Z., Glaeser, E., Litan, R., Fleming, L., Goetz, S., Kerr, W., Klepper, S., Rosenthal, S., Sorenson, O. and Strange, W. (2008b). Entrepreneurship and urban success: Toward a policy consensus. Kauffman Foundation.

Ardagna, S., \& Lusardi, A. (2009). Where does regulation hurt? Evidence from new businesses across countries (No. w14747). National Bureau of Economic Research.

Ardagna, S., \& Lusardi, A. (2010). Heterogeneity in the effect of regulation on entrepreneurship and entry size. Journal of the European Economic Association, 8(2- 3), 594-605.

Armington, C., \& Acs, Z., (2002). The determinants of regional variation in new firm formation. Regional Studies 36(1), 33-45.

\footnotetext{
${ }^{2}$ We thank reviewers for noting this limitation in our dependent variable and suggesting relevant examples.
} 
Audretsch, D. \& Belitski, M. (2017). Entrepreneurial ecosystems in cities: establishing the framework conditions. The Journal of Technology Transfer, 42(5), 1030-1051.

Audretsch, D., Belitski, M., \& Desai, S. (2015). Entrepreneurship and economic development in cities. The Annals of Regional Science, 55(1), 33-60.

Audretsch, D, \& Lehmann, E. (2016). The seven secrets of Germany. Oxford University Press. Autio, E., Kenney, M., Mustar, P., Siegel, D.S., \& Wright, M., (2014). Entrepreneurial innovation: The importance of context. Research Policy 43(7), 1097-1108.

Baliamoune-Lutz, M., \& Garello, P., (2014). Tax structure and entrepreneurship. Small Business Economics 42, 165-190.

Baumol, W., (1990). Entrepreneurship: Productive, unproductive and destructive. Journal of Political Economy 98(5), 893-921.

Belitski, M., Chowdhury, F., \& Desai, S., (2016). Taxes, corruption, and entry. Small Business Economics 47(1), 201-216.

Belitski, M., \& Desai, S., (2015). What drives ICT clustering in European cities? Journal of Technology Transfer, 1-21.

Bergmann, H., \& Sternberg, R. (2007). The changing face of entrepreneurship in Germany. Small Business Economics, 28(2-3), 205-221.

Boschma, R. and Fritsch, M. (2009) Creative class and regional growth: Empirical evidence from seven European countries. Economic Geography, 85(4): 391-423.

Bosma, N., \& Sternberg, R., (2014). Entrepreneurship as an urban event? Empirical evidence from European cities. Regional Studies 48, 1016-1033.

Braunerhjelm, P., Desai, S., \& Eklund, J. E. (2015). Regulation, firm dynamics and entrepreneurship. European Journal of Law and Economics, 40(1), 1-11.

Bruton, G., Ahlstrom, D., \& Li, H., (2010). Institutional theory and entrepreneurship: Where are we now and where do we need to move in the future? Entrepreneurship Theory and Practice 34(3), 421-440.

Certo, S. T., Withers, M. C., \& Semadeni, M. (2016). A tale of two effects: Using longitudinal data to compare within- and between- firm effects. Strategic Management Journal.

Charron, N., Dijkstra, L., \& Lapuente, V., (2014). Regional governance matters: quality of government within European Union member states. Regional Studies 48(1), 68-90.

Davidsson, P., Lindmark, L. and Olofsson, C. (1994). New firm formation and regional development in Sweden. Regional Studies, 28, 395-410

Desai, S., Acs, Z. and Weitzel, U. (2013) A model of destructive entrepreneurship: Insight for conflict and postconflict recovery. Journal of Conflict Resolution, 57(1): 20-40.

De Soto, H., (1989). The Other Path. New York: Harper and Row.

Ding, Z., Au, K., \& Chiang, F. (2015). Social trust and angel investors' decisions: A multilevel analysis across nations. Journal of Business Venturing, 30(2), 307-321.

Djankov, S., La Porta, R., Lopez-de-Silanes, F., \& Shleifer, A., (2002). The regulation of entry. Quarterly Journal of Economics 117(1), 1-37.

Djankov, S., Ganser, T., McLiesh, C., Ramalho, R., \& Shleifer, A., (2009). The effect of corporate taxes on investment and entrepreneurship. AEJ: Macroeconomics 2, 31-64.

Eskridge Jr, W. (1988). Politics without romance: implications of public choice theory for statutory interpretation. Virginia Law Review, 275-338.

Estrin, S., Korosteleva, J., \& Mickiewicz, T., (2013) Which institutions encourage entrepreneurial growth aspirations? Journal of Business Venturing, 28(4), 564-580. 
Estrin, S. \& Mickiewicz, T. (2012) Shadow economy and entrepreneurial entry. Review of Development Economics, 16(4): 559-578.

European Commission. (2007). The State of European cities report.

Eurostat (2011). City statistics Urban audit.

Feldman, M. (2001) The entrepreneurial event revisited. Industrial and Corporate Change 10, 861-891.

Fogel, K., Hawk, A., Morck, R., \& Yeung, B. (2006). Institutional obstacles to entrepreneurship. In: Casson, M., Yeung, B., Basu, A., Wedeson, N. (Eds.), The Oxford Handbook of Entrepreneurship. Oxford University Press, Oxford, pp. 540-579.

Fritsch, M. \& Storey, D. (2014). Entrepreneurship in a regional context. Regional Studies 48(6), 939-954.

Glaeser, E., Kerr, W., \& Ponzetto, G., (2010a). Clusters of entrepreneurship. Journal of Urban Economics 67(1), 150-168.

Glaeser, E., Rosenthal, S., \& Strange, W., (2010b). Urban economics and entrepreneurship. Journal of Urban Economics 67(1), 1-14.

Goldstein, H., (2005). Multilevel models. John Wiley \& Sons, Ltd.

Hantke-Domas, M., (2003). The public interest theory of regulation: non-existence or misinterpretation?. European journal of law and economics, 15, 165-194.

Hundt, C., \& Sternberg, R. (2016). Explaining new firm creation in Europe from a spatial and time perspective. Papers in Regional Science, 95(2), 223-257.

Jacobs, J. 1970. The economy of cities. Vintage Books Edition, Random House, New York. Johnson, P., McMillan, J., \& Woodruff, C., (1999). Contract enforcement in transition. EBRD Working Paper No. 45.

Keeble, D. and Walker, S. (1994) New firms, small firms and dead firms: Spatial patterns and determinants in the United Kingdom. Regional Studies, 28(4): 411-427.

Klapper, L., Laeven, L., \& Rajan, R., (2006). Entry regulation as barrier to entrepreneurship. Journal of Financial Economics 82, 591-629.

Lind, J. T., \& Mehlum, H. (2010). With or without U? the appropriate test for a U- shaped relationship. Oxford bulletin of economics and statistics, 72(1), 109-118.

Marshall, A., (1890) Principles of Economics, Macmillan, London.

McCulloch, CE., Searle, SR., \& Neuhaus, JM., (2008). Generalized, Linear, and Mixed Models.

2nd ed. Hoboken, NJ: Wiley.

North, D. (1990). Institutions, Institutional Change and Economic Performance. Cambridge University Press, Cambridge.

Papke, L. E., \& Wooldridge, J. M. (2008). Panel data methods for fractional response variables with an application to test pass rates. Journal of Econometrics, 145(1), 121-133.

Peltzman, S. (1976) Toward a more general theory of regulation. Journal of Law and Economics, 19(2): 211-240.

Pigou, A. C., (1938). The Economics of Welfare, 4th ed. London: Macmillan.

Rabe-Hesketh, S., \& Skrondal, A., (2012). Multilevel and Longitudinal Modeling Using Stata. $3 r d$ ed. College Station, TX: Stata Press.

Reynolds, P., Storey, D., \& Westhead, P., (1994). Cross-national comparison of the variation in new firm formation rates. Regional Studies 28, 443-456.

Spigel, B., (2016). Developing and governing entrepreneurial ecosystems: The structure of entrepreneurial support programs in Edinburgh, Scotland. International Journal of Innovation and Regional Development, 7(2): 141-160. 
Spigel, B. (2017). The relational organization of entrepreneurial ecosystems. Entrepreneurship Theory and Practice, 41(1): 49-72.

Stenholm, P, Acs, Z, \& Wuebker, R. (2013). Exploring country-level institutional arrangements on the rate and type of entrepreneurial activity. Journal of Business Venturing 28(1), 176-193. Thurik, R., Carree, M., van Stel, A., \& Audretsch, D., (2008). Does Self-Employment Reduce Unemployment? Journal of Business Venturing 23, 673-686.

Transparency International (2012). Corruption Perceptions Report.

Tullock, G., (1967) The welfare cost of tariffs, monopoly, and theft. Western Economic Journal $V, 224-232$.

Van Stel, A., Storey, D., \& Thurik, A., (2007). The effect of business regulations on nascent and young business entrepreneurship. Small Business Economics 28(2-3), 171-186.

Welter, F. (2011). Conceptualizing entrepreneurship - conceptual challenges and ways forward. Entrepreneurship Theory and Practice 35, 165-184.

Westlund, H., Larsson, JP., \& Olsson AR., (2014). Start-ups and local entrepreneurial social capital in the municipalities of Sweden. Regional studies 48(6), 974-994.

Whitley, R. (1999). Divergent capitalisms. OUP Oxford.

Williamson, O., (2000). New institutional economics. Journal of Economic Literature 38, 595.

Wooldridge J. (2002). Econometric analysis of cross section and panel data. MIT Press. 
Table 1: Correlation Matrix

\begin{tabular}{|c|c|c|c|c|c|c|c|c|c|c|c|c|c|c|c|c|c|c|c|c|}
\hline & Mean & S.D. & 1 & 2 & 3 & 4 & 5 & 6 & 7 & 8 & 9 & 10 & 11 & 12 & 13 & 14 & 15 & 16 & 17 & 18 \\
\hline 1. City entrepreneurship & 14.64 & 9.95 & 1.00 & & & & & & & & & & & & & & & & & \\
\hline 2. Entry procedures & 7.52 & 2.23 & $0.09 *$ & 1.00 & & & & & & & & & & & & & & & & \\
\hline $\begin{array}{l}\begin{array}{l}\text { 3. Property registration } \\
\text { procedures }\end{array} \\
\end{array}$ & 5.77 & 1.80 & $0.14 *$ & $-0.10^{*}$ & 1.00 & & & & & & & & & & & & & & & \\
\hline 4. Paying taxes procedures & 24.68 & 25.08 & -0.09 & -0.04 & $0.38^{*}$ & 1.00 & & & & & & & & & & & & & & \\
\hline $\begin{array}{l}\text { 5. Enforcing contracts } \\
\text { procedures }\end{array}$ & 31.99 & 3.95 & $-{ }^{-}$ & $0.50 *$ & $-0.17 *$ & $0.16^{*}$ & 1.00 & & & & & & & & & & & & & \\
\hline 6. Entry cost & 9.32 & 8.12 & $0.28 *$ & $0.46^{*}$ & $-0.21 *$ & $0.14^{*}$ & $0.64^{*}$ & 1.00 & & & & & & & & & & & & \\
\hline $\begin{array}{l}\text { 7. Property registration } \\
\text { cost }\end{array}$ & 4.69 & 3.07 & -0.08 & $-0.34 *$ & 0.00 & $-0.46^{*}$ & $-0.23^{*}$ & 0.03 & 1.00 & & & & & & & & & & & \\
\hline 8. Paying taxes cost & 50.43 & 8.78 & -0.02 & $-0.17^{*}$ & $0.27^{*}$ & -0.01 & -0.07 & -0.09 & $0.41^{*}$ & 1.00 & & & & & & & & & & \\
\hline 9. Enforcing contracts cost & 17.95 & 5.07 & $\overline{-} 09^{*}$ & $-0.40^{*}$ & $-0.18^{*}$ & -0.06 & $-0.45^{*}$ & $-0.43^{*}$ & -0.02 & -0.04 & 1.00 & & & & & & & & & \\
\hline 10. CPI & 6.36 & 1.94 & $0.23 *$ & $-0.36^{*}$ & $-0.25^{*}$ & $-0.67^{*}$ & $-0.56^{*}$ & $-0.50^{*}$ & $0.40^{*}$ & -0.01 & $0.25^{*}$ & 1.00 & & & & & & & & \\
\hline 11. GDP & 9.84 & 0.57 & $0.31^{*}$ & $-0.17 *$ & $-0.14 *$ & $-0.58^{*}$ & $-0.49 *$ & $-0.43 *$ & $0.31^{*}$ & 0.00 & $0.09 *$ & $0.69^{*}$ & 1.00 & & & & & & & \\
\hline 12. Density & 7.27 & 0.85 & 0.06 & $0.14 *$ & $0.14^{*}$ & $0.17^{*}$ & -0.01 & 0.04 & $-0.10^{*}$ & $-0.17^{*}$ & -0.04 & -0.08 & $0.16^{*}$ & 1.00 & & & & & & \\
\hline 13. Pop at work & 12.08 & 0.83 & 0.07 & -0.04 & $0.10^{*}$ & -0.05 & -0.04 & $-0.10^{*}$ & 0.01 & 0.08 & -0.01 & $0.09^{*}$ & $0.40^{*}$ & $0.55^{*}$ & 1.00 & & & & & \\
\hline 14. Agriculture & 1.08 & 1.62 & 0.00 & $0.09^{*}$ & $-0.12^{*}$ & 0.02 & $0.28^{*}$ & $0.14 *$ & $0.19^{*}$ & $0.24 *$ & 0.00 & $-0.09^{*}$ & $-0.20^{*}$ & $-0.27^{*}$ & $-0.20^{*}$ & 1.00 & & & & \\
\hline 15. Manufacturing & 18.91 & 9.41 & $0.13^{-}$ & $0.12 *$ & 0.02 & $0.57^{*}$ & $0.42^{*}$ & $0.39^{*}$ & $-0.27^{*}$ & -0.04 & $-0.14 *$ & $-0.68^{*}$ & $-0.69^{*}$ & -0.06 & $-0.30^{*}$ & $0.13^{*}$ & 1.00 & & & \\
\hline 16. Retail & 18.30 & 3.61 & 0.03 & $0.10^{*}$ & $-0.14 *$ & $-0.17^{*}$ & $0.13^{*}$ & -0.01 & 0.08 & $-0.13^{*}$ & $0.15^{*}$ & 0.01 & -0.01 & $0.08^{*}$ & 0.08 & $0.17^{*}$ & -0.01 & 1.00 & & \\
\hline 17. Finance & 15.69 & 7.06 & $0.26^{*}$ & $-0.15^{*}$ & -0.07 & $-0.43^{*}$ & $-0.49 *$ & $-0.28 *$ & $0.19^{*}$ & $-0.16^{*}$ & $0.11^{*}$ & $0.63^{*}$ & $0.69^{*}$ & $0.27^{*}$ & $0.44 *$ & $-0.33^{*}$ & $-0.65^{*}$ & -0.04 & 1.00 & \\
\hline 18. Public & 33.43 & 7.35 & 0.00 & $-0.25^{*}$ & 0.04 & $-0.34 *$ & $-0.36^{*}$ & $-0.13^{*}$ & $0.39 *$ & $0.28^{*}$ & -0.06 & $0.41^{*}$ & $0.24^{*}$ & $-0.28^{*}$ & $-0.15^{*}$ & $-0.09 *$ & $-0.46^{*}$ & $-0.25^{*}$ & $0.12 *$ & 1.00 \\
\hline 19. ITC & 1.01 & 1.68 & $0.11^{*}$ & -0.02 & $-0.21 *$ & $-0.17^{*}$ & -0.03 & -0.05 & 0.08 & $0.09 *$ & -0.03 & 0.03 & 0.05 & -0.06 & -0.04 & 0.03 & $0.20^{*}$ & $0.10^{*}$ & 0.00 & -0.05 \\
\hline
\end{tabular}

Note: The matrix is calculated using the full sample of 496 obs. (228 cities, 20 countries). Level of statistical significance is * $0.05 \%$. Correlations for the 12 city typologies are suppressed to save space.

Source: UAP = Urban Audit Project (Eurostat 2011); DB = Doing Business Statistics (2012); TI = Transparency International (2012). 
Table 2: Multilevel Multivariate Regression Main Effects Model (DV - city level entrepreneurship) ${ }^{\dagger}$

\begin{tabular}{|c|c|c|c|c|c|c|}
\hline & Sample & & \multicolumn{2}{|c|}{ Full sample } & \multicolumn{2}{|c|}{ Reduced sample } \\
\hline & Model type & baseline & procedures & cost & Procedures & Cost \\
\hline & Specification & (1) & (2) & (3) & (4) & (5) \\
\hline \multirow{9}{*}{ d } & Entry & & $\begin{array}{c}6.37 * * \\
(1.44)\end{array}$ & $\begin{array}{c}-1.11^{* *} \\
(0.29)\end{array}$ & $\begin{array}{l}0.96^{\dagger} \\
(0.44)\end{array}$ & $\begin{array}{c}-1.16^{* *} \\
(0.26)\end{array}$ \\
\hline & Entry squared & & $\begin{array}{l}-0.48^{* *} \\
(0.10)\end{array}$ & $\begin{array}{l}0.02 * * \\
(0.01)\end{array}$ & $\begin{array}{l}-0.20^{*} \\
(0.09)\end{array}$ & $\begin{array}{l}0.02 * * \\
(0.00)\end{array}$ \\
\hline & $\begin{array}{l}\text { Property registration } \\
\text { cost }\end{array}$ & & $\begin{array}{c}-21.43 * * \\
(3.23) \\
\end{array}$ & $\begin{array}{c}-4.53^{* *} \\
(0.99)\end{array}$ & $\begin{array}{c}-28.39 * * \\
(2.81) \\
\end{array}$ & $\begin{array}{c}-5.94 * * \\
(0.89) \\
\end{array}$ \\
\hline & $\begin{array}{l}\text { Property registration } \\
\text { cost squared }\end{array}$ & & $\begin{array}{l}1.57 * * \\
(0.29)\end{array}$ & $\begin{array}{l}0.28^{* *} \\
(0.10)\end{array}$ & $\begin{array}{l}1.97 * * \\
(0.26)\end{array}$ & $\begin{array}{l}0.43 * * \\
(0.09)\end{array}$ \\
\hline & Paying taxes & & $\begin{array}{l}-0.17 \\
(0.16)\end{array}$ & $\begin{array}{l}-2.87 * * \\
(1.03)\end{array}$ & $\begin{array}{l}-0.12 \\
(0.14)\end{array}$ & $\begin{array}{c}-2.99 * * \\
(0.92)\end{array}$ \\
\hline & Paying taxes squared & & $\begin{array}{c}0.89 \\
(0.00)\end{array}$ & $\begin{array}{l}0.03 * * \\
(0.01)\end{array}$ & $\begin{array}{l}-0.57 \\
(0.00)\end{array}$ & $\begin{array}{l}0.03 * * \\
(0.01)\end{array}$ \\
\hline & Enforcing contracts & & $\begin{array}{l}-10.46 \\
(8.49)\end{array}$ & $\begin{array}{c}0.80 \\
(2.07)\end{array}$ & $\begin{array}{l}-10.40 \\
(9.25)\end{array}$ & $\begin{array}{c}0.68 \\
(1.76)\end{array}$ \\
\hline & Enforcing contracts squared & & $\begin{array}{c}0.16 \\
(0.13) \\
\end{array}$ & $\begin{array}{l}-0.02 \\
(0.05) \\
\end{array}$ & $\begin{array}{c}0.17 \\
(0.14) \\
\end{array}$ & $\begin{array}{l}-0.01 \\
(0.04) \\
\end{array}$ \\
\hline & CPI & & $\begin{array}{c}0.95 \\
(0.69)\end{array}$ & $\begin{array}{c}0.53 \\
(0.66)\end{array}$ & $\begin{array}{l}-2.67 * * \\
(0.65)\end{array}$ & $\begin{array}{c}-1.10^{\dagger} \\
(0.60)\end{array}$ \\
\hline \multirow{11}{*}{ 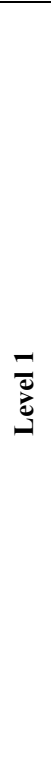 } & GDP & & $\begin{array}{c}-39.36^{* *} \\
(13.91)\end{array}$ & $\begin{array}{l}-34.10^{*} \\
(15.18) \\
\end{array}$ & $\begin{array}{c}-9.73 \\
(13.52) \\
\end{array}$ & $\begin{array}{l}-21.15 \\
(15.98) \\
\end{array}$ \\
\hline & GDP squared & & $\begin{array}{l}1.83 * * \\
(0.70)\end{array}$ & $\begin{array}{l}1.60^{*} \\
(0.77)\end{array}$ & $\begin{array}{c}0.41 \\
(0.70)\end{array}$ & $\begin{array}{c}1.01 \\
(0.83)\end{array}$ \\
\hline & Density & & $\begin{array}{l}-0.04 \\
(0.39) \\
\end{array}$ & $\begin{array}{l}-0.01 \\
(0.41) \\
\end{array}$ & $\begin{array}{c}0.14 \\
(0.33) \\
\end{array}$ & $\begin{array}{c}0.10 \\
(0.39) \\
\end{array}$ \\
\hline & Population at work & & $\begin{array}{l}0.70^{\dagger} \\
(0.41)\end{array}$ & $\begin{array}{l}0.77^{\dagger} \\
(0.46)\end{array}$ & $\begin{array}{c}0.07 \\
(0.39)\end{array}$ & $\begin{array}{c}0.34 \\
(0.46)\end{array}$ \\
\hline & Agriculture & & $\begin{array}{c}0.06 \\
(0.17) \\
\end{array}$ & $\begin{array}{c}0.12 \\
(0.19) \\
\end{array}$ & $\begin{array}{c}0.18 \\
(0.15) \\
\end{array}$ & $\begin{array}{c}0.17 \\
(0.17) \\
\end{array}$ \\
\hline & Manufacturing & & $\begin{array}{c}0.0375 \\
(0.05) \\
\end{array}$ & $\begin{array}{l}0.0880 \\
(0.06) \\
\end{array}$ & $\begin{array}{l}0.0423 \\
(0.04) \\
\end{array}$ & $\begin{array}{c}0.0838 \\
(0.05) \\
\end{array}$ \\
\hline & Retail & & $\begin{array}{l}0.021 \\
(0.07)\end{array}$ & $\begin{array}{c}0.02 \\
(0.08) \\
\end{array}$ & $\begin{array}{l}0.15^{*} \\
(0.07)\end{array}$ & $\begin{array}{c}0.07 \\
(0.08)\end{array}$ \\
\hline & Finance & & $\begin{array}{l}0.14^{\dagger} \\
(0.08)\end{array}$ & $\begin{array}{l}0.18^{*} \\
(0.08)\end{array}$ & $\begin{array}{c}0.08 \\
(0.07)\end{array}$ & $\begin{array}{c}0.12 \\
(0.08)\end{array}$ \\
\hline & Public & & $\begin{array}{l}-0.04 \\
(0.05) \\
\end{array}$ & $\begin{array}{c}0.02 \\
(0.06) \\
\end{array}$ & $\begin{array}{l}-0.06 \\
(0.05)\end{array}$ & $\begin{array}{c}0.03 \\
(0.06) \\
\end{array}$ \\
\hline & ICT & & $\begin{array}{l}-0.293^{*} \\
(0.14) \\
\end{array}$ & $\begin{array}{c}-0.304^{*} \\
(0.15) \\
\end{array}$ & $\begin{array}{c}-0.342^{*} \\
(0.16) \\
\end{array}$ & $\begin{array}{c}-0.395^{*} \\
(0.19) \\
\end{array}$ \\
\hline & Constant & $\begin{array}{c}12.55 * * \\
(1.35) \\
\end{array}$ & $\begin{array}{l}418.6^{* *} \\
(148.11) \\
\end{array}$ & $\begin{array}{l}248.3^{* *} \\
(77.58) \\
\end{array}$ & $\begin{array}{c}321.5 \\
(154.10) \\
\end{array}$ & $\begin{array}{l}195.8^{*} \\
(77.71) \\
\end{array}$ \\
\hline \multirow{8}{*}{ 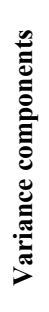 } & Within-Country (estimate) & 32.65 & 148.33 & 78.26 & 232.22 & 54.74 \\
\hline & Within-Country (S.E) & 10.79 & 64.21 & 31.5 & 108.32 & 27.95 \\
\hline & Intercept variance (estimate) & 29.19 & 18.14 & 20.84 & 11.93 & 16.78 \\
\hline & Residual variance (S.E) & 1.88 & 1.19 & 1.36 & 0.86 & 1.21 \\
\hline & ICC & 0.53 & 0.89 & 0.78 & 0.93 & 0.76 \\
\hline & LR test vs. linear regression & & 444.13 & 359.86 & 118.42 & 42.02 \\
\hline & Wald chi-square test & 144.49 & 276.45 & 180.66 & 411.71 & 174.96 \\
\hline & Log-likelihood & -1569.5 & -1470.4 & -1497.2 & -1175.4 & -1230.1 \\
\hline
\end{tabular}

Note: Significance $\dagger 0.1 \%, * 0.05 \%, * * 0.01 \%$ do not include zero. 90\%, 95\%, 99\% confidence intervals do not include zero. Given the nonlinear model, significance may vary within an interval at level 2. Full sample=496 obs., 228 cities, 20 countries. Reduced sample $=422$ obs., 189 cities, 19 countries. City type fixed effects and year dummies control for unobserved heterogeneity across cities. City fixed effects not included in the base model (w/random intercept to test validity). Output is suppressed to save space.

Source: Authors using Eurostat (2011), Doing Business Statistics (2012); Transparency International (2012). 


\section{APPENDIX}

Figure 1: Nested multilevel model of city level entrepreneurship

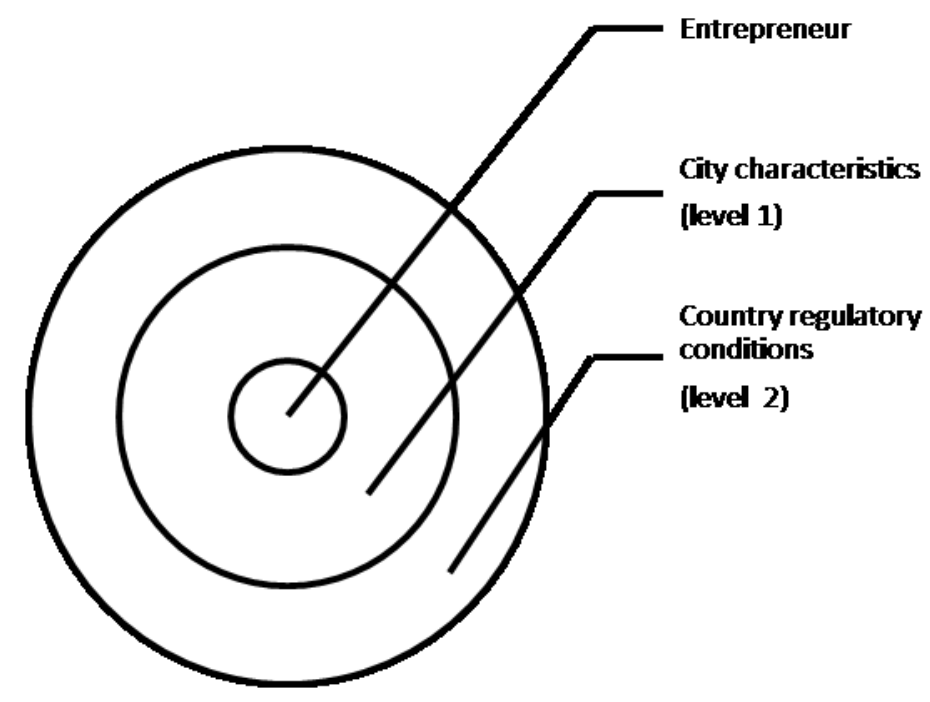

Figure 2: Average entrepreneurship in the cities in this study

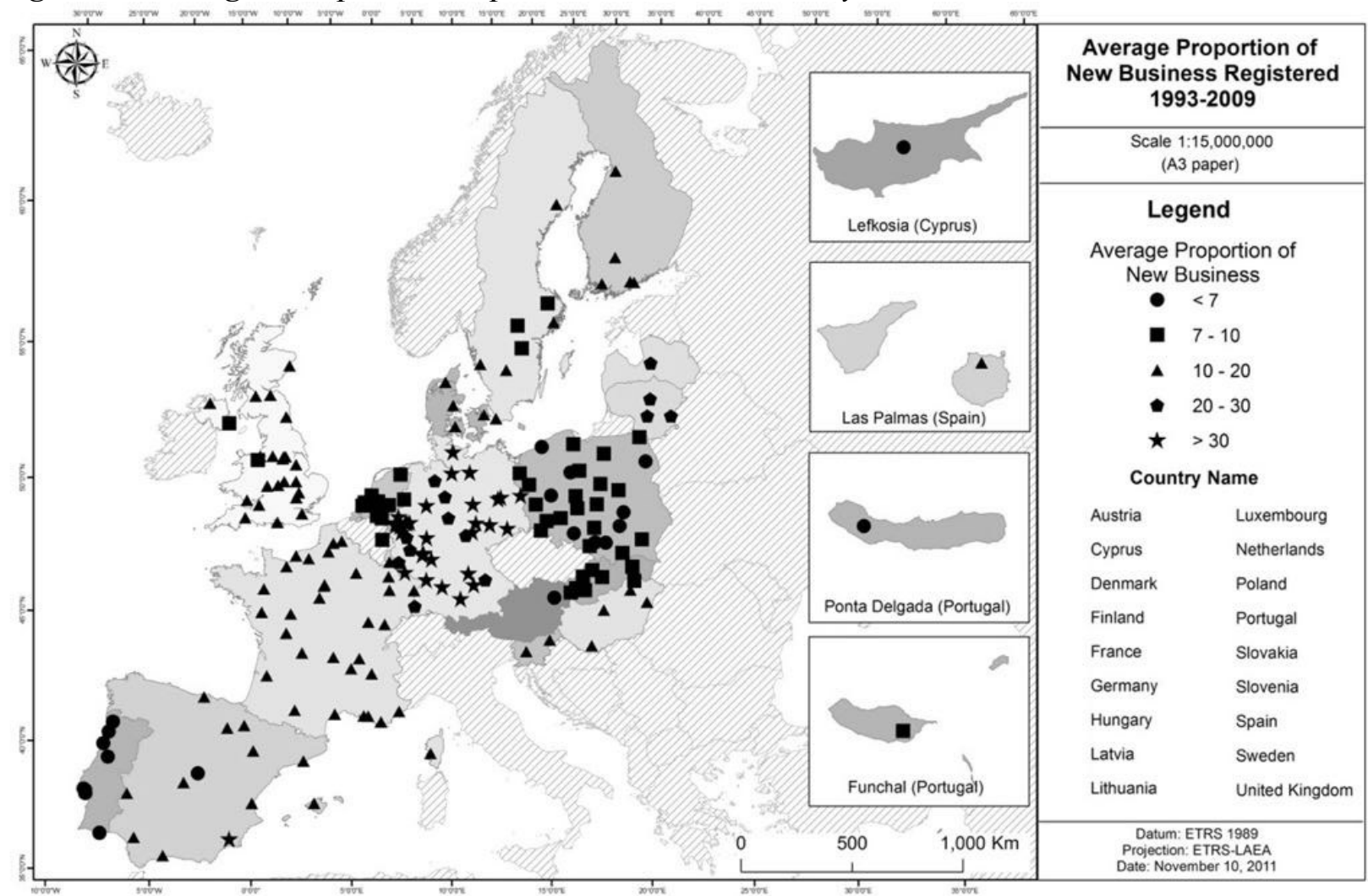

Source: Authors calculation 
Figure 3: Predictive margins with $95 \%$ confidence intervals

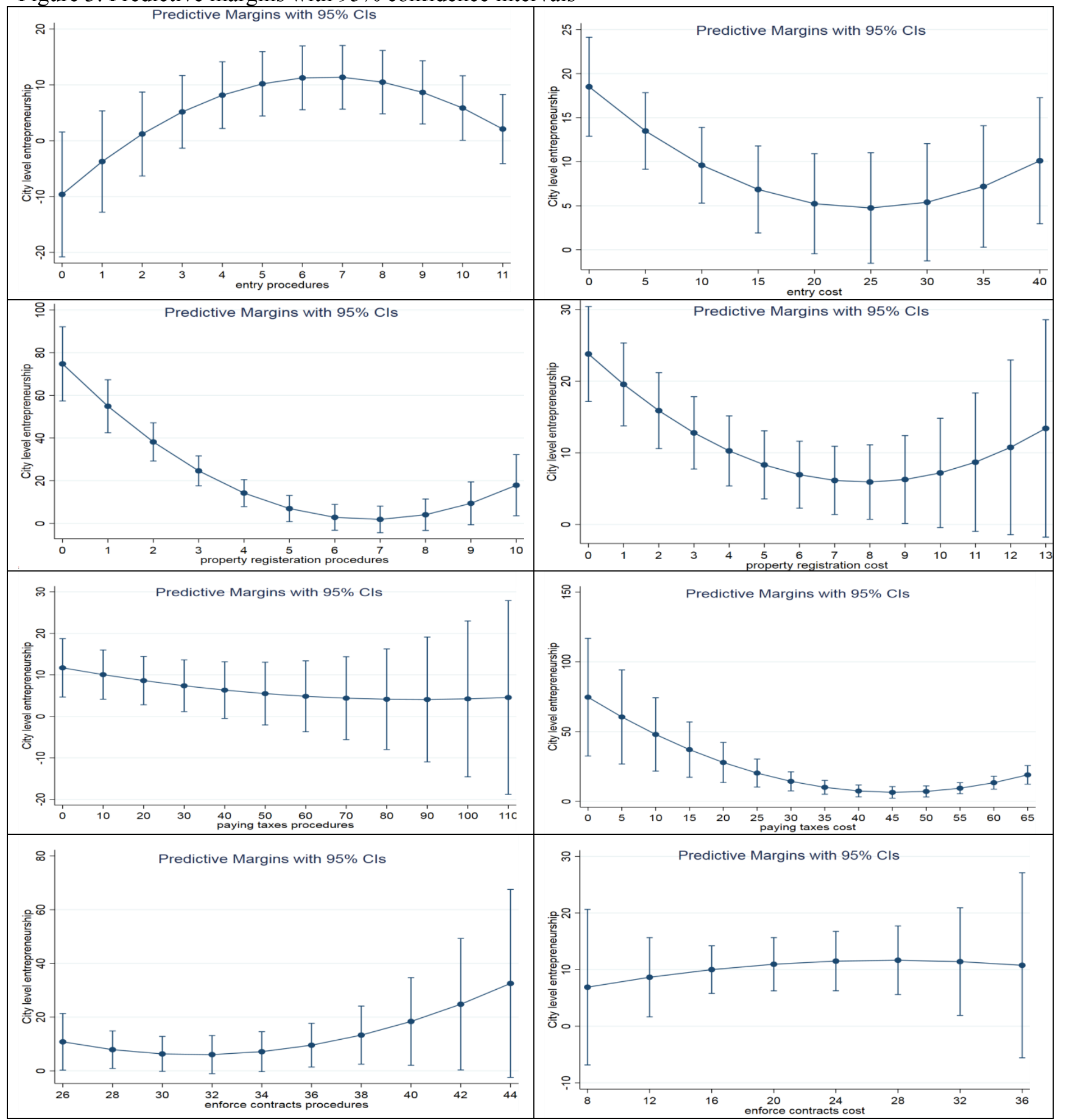

Note: Margins fit using two-level mixed-effects model and the full sample of 228 cities.

Source: Authors calculation using Eurostat (2011), Transparency International (2012), and Doing Business (2012). 